
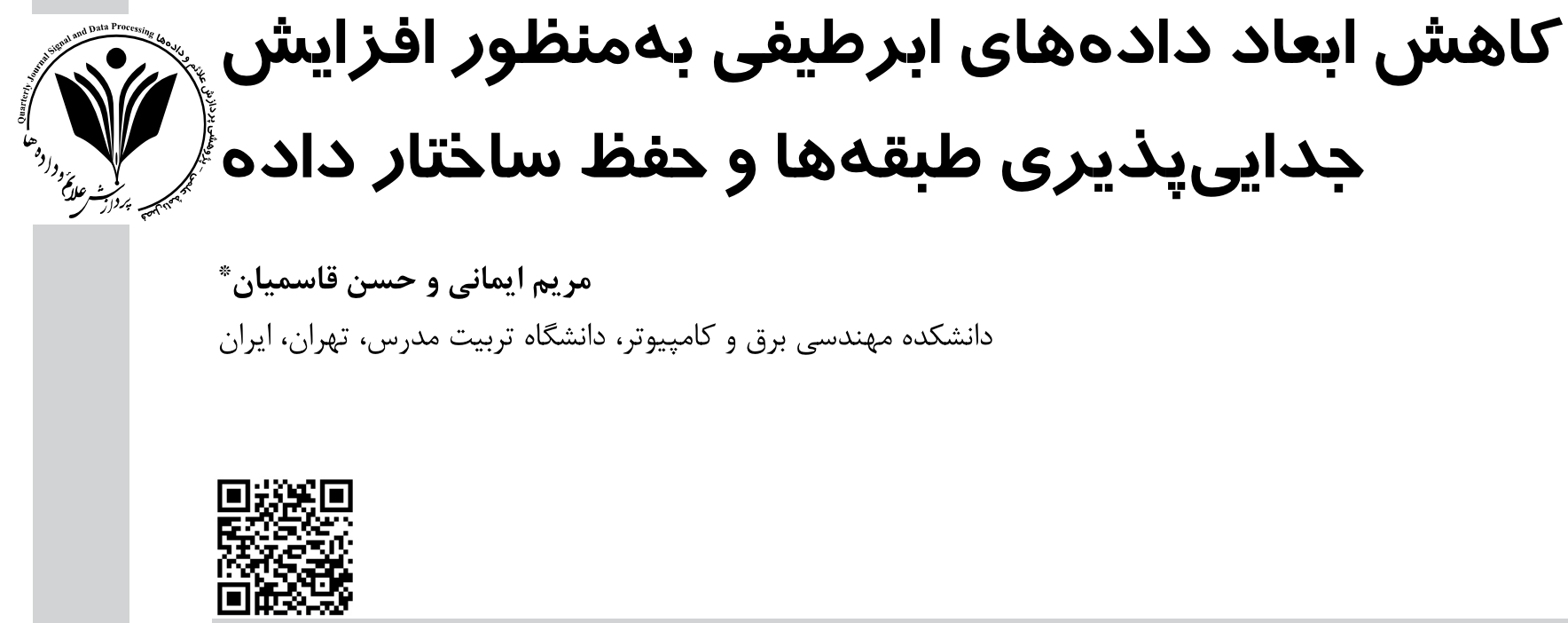

جكبله

امروزه تصويربردارى ابرطيفى بلمنظور طبقهبندى دادههاى سطح زمين با دقت و جزئيات بالا بسيار مورد توجه است. بهدليل كمبود نمونئ

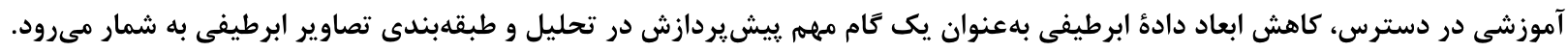

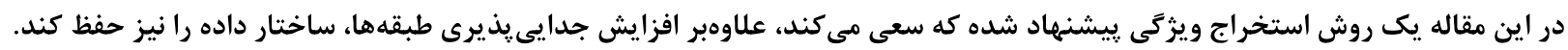

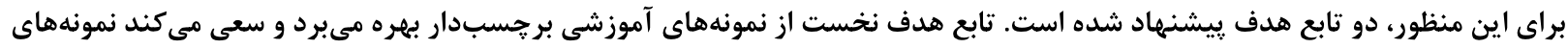

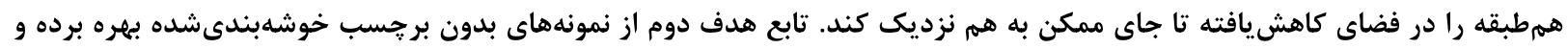

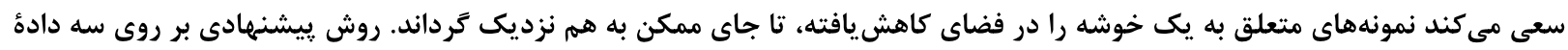

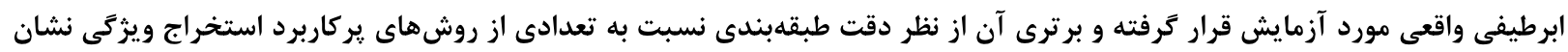

وازگًان كليدى: ابعاد بالا، نمونه آموزشى كم، ابرطيفى، طبقهبندى، كاهش ويثزى

\title{
Feature reduction of hyperspectral data for increasing of class separability and preserving of data structure
}

\author{
Maryam Imani and Hassan Ghassemian*
}

Faculty of Electrical and Computer Engineering, Tarbiat Modares University, Tehran, Iran

\begin{abstract}
Hyperspectral imaging with gathering hundreds spectral bands from the surface of the Earth allows us to separate materials with similar spectrum. Hyperspectral images can be used in many applications such as land chemical and physical parameter estimation, classification, target detection, un mixing, and so on. Among these applications, classification is especially interested. A hyperspectral image is a cube data containing two spatial dimensions and a spectral one. Generally, the Hughes phenomenon is occurred in the supervised classification of hyperspectral images due to the limited available labeled samples and the curse of dimensionality. So, feature reduction is an important preprocessing step for analysis and classification of hyperspectral data. Feature reduction methods are categorized into feature selection approaches and feature extraction ones. Our main focus in this paper is on feature extraction. The feature extraction methods are also divided into three main groups: supervised (with labeled samples), unsupervised (without labeled samples), and semi-supervised (with both labeled and unlabeled samples). The first group of feature extraction methods usually suffers from problems due to limited available training samples. These methods often consider the separability between classes, and so are efficient for classification applications. The second group has no need for training samples, but they often do not consider the separability between
\end{abstract}


different classes and so, are not appropriate for classification. These methods are usually used for signal representation or preserving the local structure of data. The use of both labeled and unlabeled samples in the third group can increase the abilities of the feature extractor. A feature extraction method is proposed in this paper which belongs to the third group. The proposed method increases the class separability and tries to preserves the structure of data. The proposed feature extraction method uses the ability of unlabeled samples in addition to available limited training samples to improve the classification performance. The experimental results on three real hyperspectral images show the better performance of proposed method compared to some popular feature extraction methods in terms of classification accuracy.

Keywords: high dimension, small training set, hyperspectral, classification, feature reduction.

استاندارد، براى انتخاب ويزگى، بهطورمعمول از توابع معيار بر

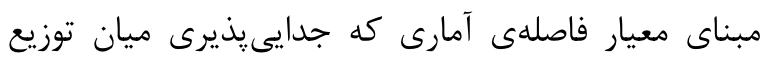

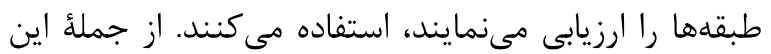

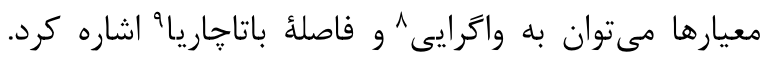
بررسى الكوريتمهاى جستجو در انتخاب ويزگى در [9 [9]-[8] انجام شده است. در [10] يك روش انتخاب ويثزى بر اساس الگوريتم جستجوى زنتيك ييشنهاد شده است. مراجع [12]-

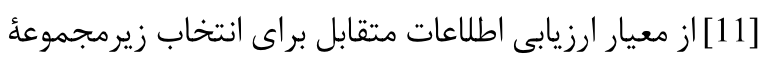
مناسب ويزگگىها استفاده كردهاند. نويسندكان در [13] براى انتخاب زيرمجموعه مناسب باندها از تركيب جندين معيار طبقهبندى از جمله جدايىيذيرى طيفى شامل فاصلئ اقليدسى، زاوئُ طيفى، همبستخى طيفى و همجنين معيار اطلاعات متقابل شامل همبستتى باندها استفاده كردهاند. در رئي [14] براى انتخاب ويزگى علاوهبر معيار جدايىيذيرى طبقهها از معيار ديخرى نيز استفاده شده است كه بر اساس اين عقيده شكل گرفته است: نمونههاى آموزشى هر طبقه كه از جاهاى مختلف تصوير انتخاب شدهاند، در ويزگى هاى مورد نظر ممكن

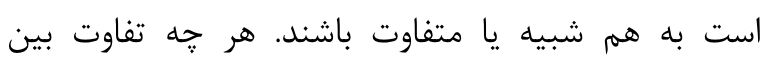
نمونههاى آموزشى هر طبقه در ويزگى هاى انتخابى كمتر باشد، بهتر است و اين باعث افزايش دقت طبقهبندى، افزايش يايورى و قدرت تعميم طبقهبندى مىشود. دسته دوم روشهاى كاهش ويزگَى، روشهاى استخراج

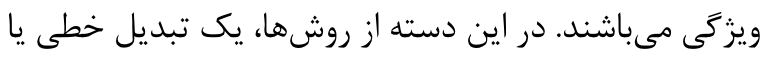
غير خطى بر روى فضاى ويزگگى اوليه اعمال مىشود تا ويززگىهاى مطلوب از آن استخراج شوند. تحليل مؤلفههاى اصلى ' (PCA) و تحليل مميز خطى " معروفترين و يركاربردترين روشهاى استخراج ويزگى در مسائل شناسايى الكو هستند [15]. اخر يك تصوير N

\footnotetext{
${ }^{7}$ Hybrid

${ }^{8}$ Divergence

${ }^{9}$ Bhattacharyya distance

${ }^{10}$ Principal Component Analysis

${ }^{11}$ Linear Discriminant Analysis
}

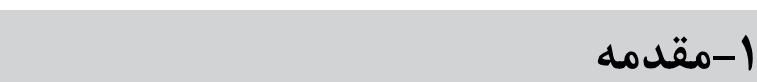
با ي يشرفت فناورى سنجندههاى اخذ تصاوير ابرطيفى '، امروزه اين تصاوير به منظورهاى مختلف شناسايى الكو، آشكارسازى بئن سطح زمين، تحليل نوع خاك، ديدهبانى و كنترل مناطق منطوري

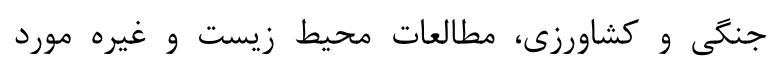

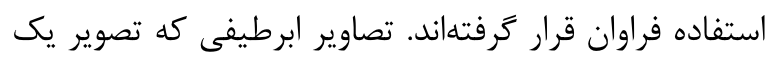
منطقه از سطح زمين را با قدرت تفكيك طيفى و مكانى بالا در صدها باند طيفى مجاور فراهم مى كنند، قادر به تفكيك دقيق يديدههاى مختلف سطح زمين و تشخيص جزئيات آنها است؛ اما همة باندهاى طيفى موجود در تصاوير ابرطيفى نمىتوانند نقش مهمى در تشخيص و طبقهبندى داده ايفا كنند؛ جون باندهاى طيفى مجاور، حاوى اطلاعات زائد و هميوشان هستند. باعلاوه، براى تحليل و طبقهبندى حجم باى زيادى از ويزگى هاى طيفى به تعداد زيادى از نمونههاى

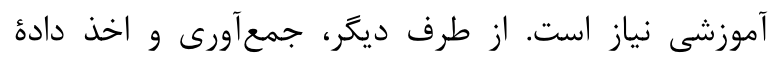
آموزشى دشوار و نيازمند صرف زمان و هزينه است. تحليل و

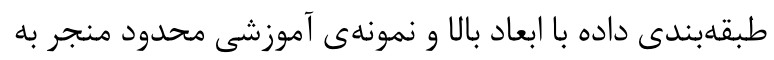

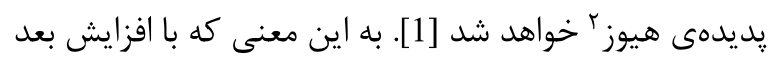

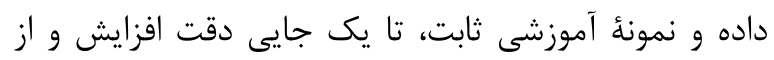

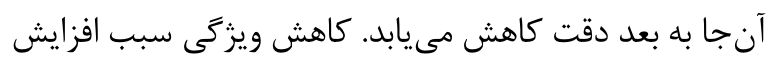
دقت طبقهبندى، كاهش حجم داده و تفسير راحتتر داده ابرطيفى خواهد شد. كاهش بعد به دو روش كلى انتخاب

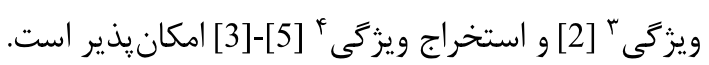

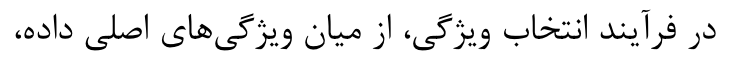

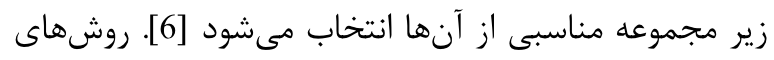

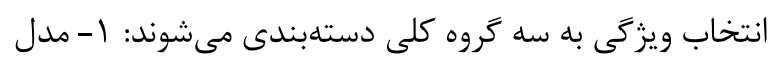

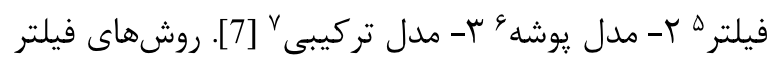

\footnotetext{
${ }^{1}$ Hyperspectral

2 Hughes phenomenon

3 Feature selection

${ }^{4}$ Feature extraction

${ }^{5}$ Filter

${ }^{6}$ Wrapper
} 
به نمونه آموزشى زياد براى يادكيرى، با استفاده از نمونه

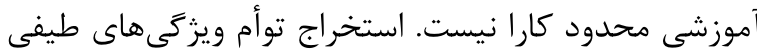
و مكانى نيز در [26] ييشنهاد و بررسى شده است. روشهاى استخراج ويزگى خطى از طريق نكاشت داده از

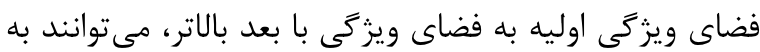

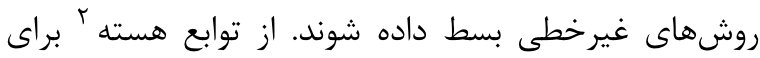
محاسبة ضرب داخلى در فضاى بعد بالاتر استفاده مىشود.

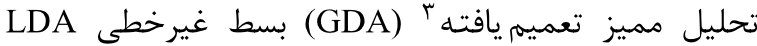
است [27]. روش GDA هم مانند LDA بيشينه قادئه استخراج 1 - 1 ويزگ

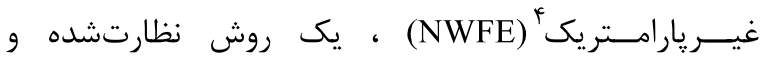

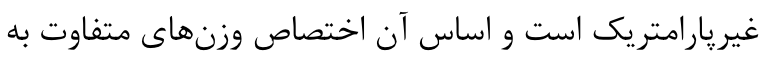

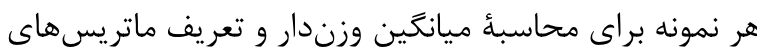
يراكندگى درونطبقهاى و بينطبقهاى غيريارامتريك جديد براى استخراج بيش از 1 اساسى روش NWFE، زمان محاسباتى بسيار زياد آن است. روش ييشنهادى [29] تحليل تمييز محلى نيمهنظارت

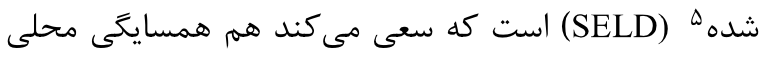
را حفظ و همم تميز بين طبقهها را بيشينه كند و براى اين كار يك روش بدون نظارت مثل جاسازى حفظ همسايكى

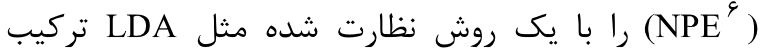
مى كند و هيج يارامتر آزادى كه لزوم به تنظيم آن باشد، نيز

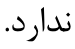

روش SELD برخلاف روشهاى نيمهنظارتشده ديكر،

تركيب نظارتشده و بدون نظارت را بهصورت خطى انجام

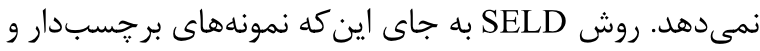

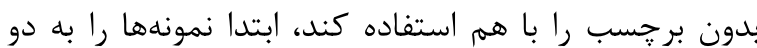
دستهى برجسبدار و بدون برجسب تقسيم مى كند و سيس

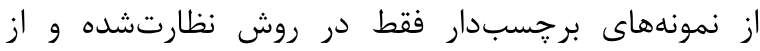
نمونههاى بدون برجسب فقط در روش بدون بدرن نظارت استفاده

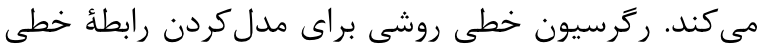

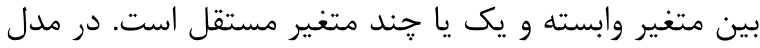
ركرسيون خطى، داده با استفاده از توابع بيشكَوى خطى مدل

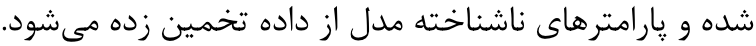

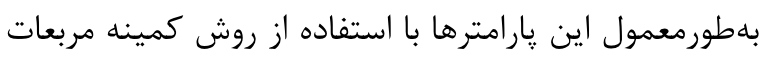

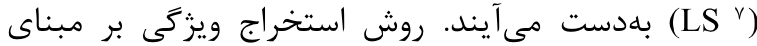
ركرسيون ستيغى (FERR (مه در [30] بيشنهاد شده است،

5 Semi-supervised local discriminant analysis

${ }^{6}$ Neighborhood preserving embedding

${ }^{7}$ Least square

${ }^{8}$ Feature extraction based on ridge regression

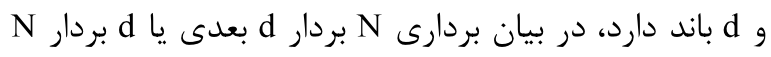
تايى داريم كه اولى بيان طيفى و دومى بيان مكانى تصوير بارداري هستند. در بيان تنسور، به جاى استفاده از بردار، براى بئ بيان

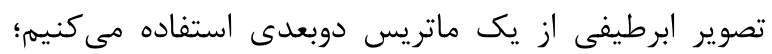

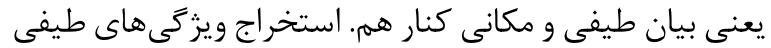
و مكانى با استفاده از بيان تنسور در [16] ييشنهاد شده استان.

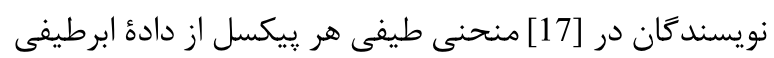
را مانند يك سرى زمانى در نظر كرفته و دو ويزكى سرى

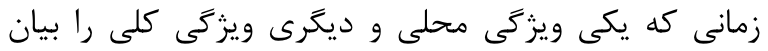

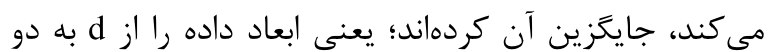

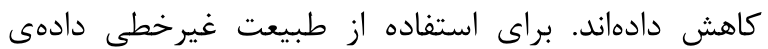

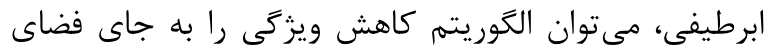
اقليدسى در فضاى غيراقليدسى اعمال كرد. استفاده از فضاى كروى براى استخراج ويزگى و طبقهبندى دادئ ابرطيفى در

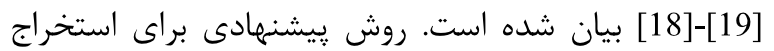

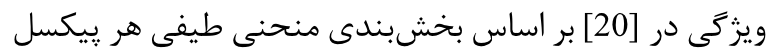

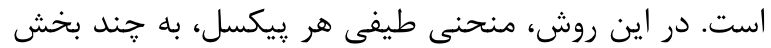

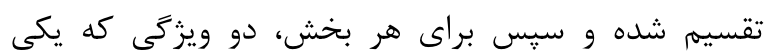
موقعيت (ميانكين) و ديخرى شكل (واريانس) آن بخش ران

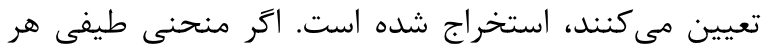

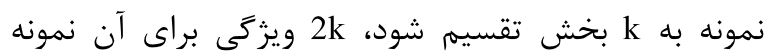

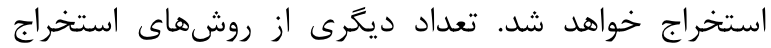
ويزگكى در [22]-[21] بيان شدهاند. استفاده از نمونههاى آموزشى مجازى، راه ديكرى براى براي

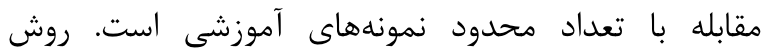

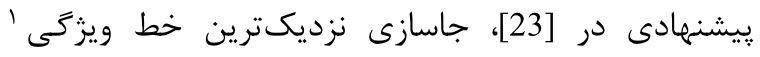
نام دارد و از مفاهيم خط ويزگى براى توليد (NFLE) نمونهاى آموزشى مجازى استفاده مى كند و از اين نمونههاى

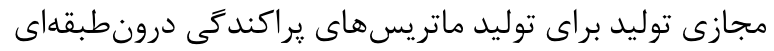

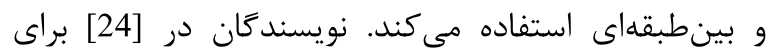
استخراج ويزگى نظارتشده از مفهوم اطلاعات متقابل استفاده

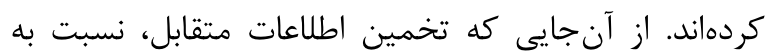

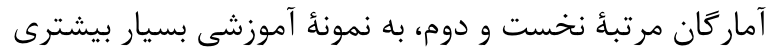
احتياج دارد، درنتيجه، اين روش با استفاده از اندازه كوجى

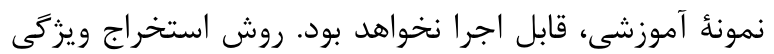
نظارتشده ديكرى با استفاده از شبكههاى عصبى در [25]

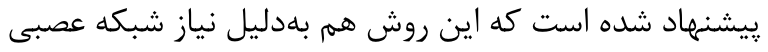

\footnotetext{
${ }^{1}$ Nearest Feature Line Embedding

Kernel

Generalized Discriminat Analysis

Nonparametric Weighted Feature Extraction
} 
$\boldsymbol{Y}=\left[\boldsymbol{y}_{1}, \boldsymbol{y}_{2}, \ldots, \boldsymbol{y}_{n}\right]_{d \times n}$

مىتوان تابع Ф را به شكل ماتريسى بازنويسىكرد.

$\Phi=\operatorname{tr}\left(\boldsymbol{Y} \boldsymbol{G}_{l} \boldsymbol{Y}^{T}\right)$

$\min _{\mathbf{A}}\left[\Phi=\operatorname{tr}\left(\boldsymbol{A}_{l} \boldsymbol{X} \boldsymbol{G}_{l} \boldsymbol{X}^{T} \boldsymbol{A}_{l}^{T}\right)\right]$

كه در روابط بالل،

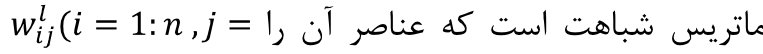

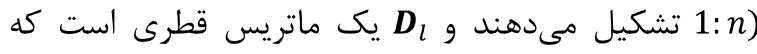
المانهاى روى قطر آن، مجموع سطرى ماتريس إس است

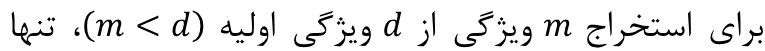
كافى است كه m بردار ويزه متناظر با m $m$ تا كوجكترين مقادير ويزه ماتريس ${ }^{\prime} \boldsymbol{G}_{l} \boldsymbol{X}^{T}$ دهند.

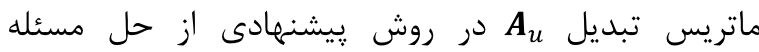
بهينهسازى زير بهدست مى آيد:

$\min \left(\Phi=\sum_{i=1}^{n} \sum_{j=1}^{n}\left\|\boldsymbol{y}_{i}-\boldsymbol{y}_{j}\right\|^{2} w_{i j}^{u}\right)$

كه

$w_{i j}^{u}=\left\{\begin{array}{lr}1 & \boldsymbol{x}_{i}^{u}, \boldsymbol{x}_{j}^{u} \text { belong to a cluster } \\ 0 & \boldsymbol{x}_{i}^{u}, \boldsymbol{x}^{u} \text { dg not belong to a cluster }\end{array}\right.$

در رابطة بالا، روش ييشنهادى، ما به همان تعداد نمونه آموزشى (n)، نمونه بدون برجسب در نظر مى گيريم. همرجنين براى انجام خوشه

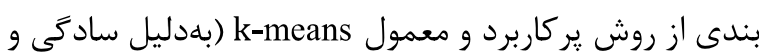
كارايى خوب آن) با نتيجه خوشهبندى k-means به انتخاب مراكز خوشهى اوليه

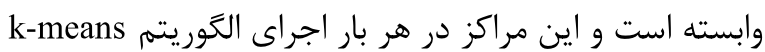
به طور تصادفى از كل داده انتخاب مىشود، ما ده مرتبه

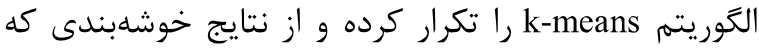
بالاترين دقت طبقهبندى را بهدست آوردهاند، بهره بردهايم.

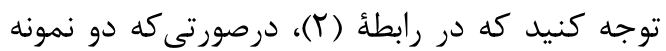

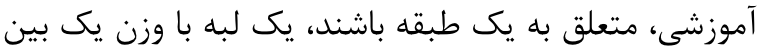

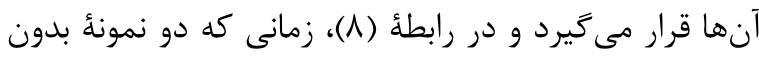

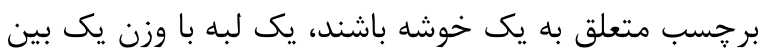

بهازاى هر باند طيفى يك بردار ويزگى تعريف كرده و ر رابطة

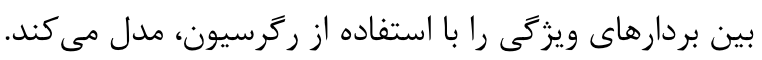
روش بيشنهادى استخراج ويزگى در اين مقاله سبب افزايش جدايىيذيرى طبقها و حفظ ساختار داده در فضاى كاهشيافته مىشود. روش يُشنيهادى، بلهعلت تعداد محدود

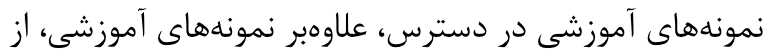
قدرت نمونههاى بدون برجسب نيز بهمنظور افزايش دقت

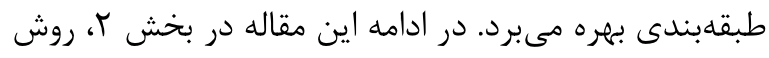
ي ييشنهادى با جزئيات بيشتر شرح داده مىشود و در بخش بَّ،

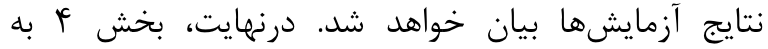
جمعبندى مقاله خواهد يرداخت.

\section{r-روش بيشنهادى}

در روش پِيشنهادى، دو دسته داده خواهيم داشت:

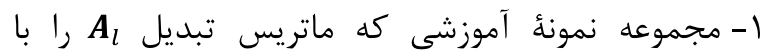
استفاده از آن مىسازيم.

T- مجموعه نمونههاى بدون برجسب كه ماتريس تبديل

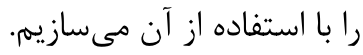

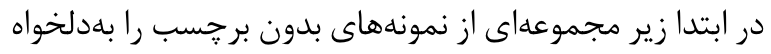

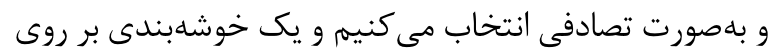
آنها انجام مى دهيم. به اين ترتيب، مجموعه نمونههاى بدون بداب

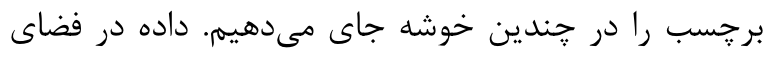

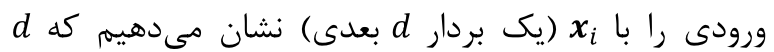
تعداد باندهاى طيفى (ويزگى هاى اوليه) است و تبديل يافتهى

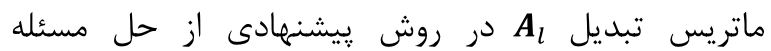
بهينهسازى زير بهدست مى آيد:

$\min \left(\Phi=\frac{1}{2} \sum_{i=1}^{n} \sum_{j=1}^{n}\left\|\boldsymbol{y}_{i}-\boldsymbol{y}_{j}\right\|^{2} w_{i j}^{l}\right)$

$w_{i j}^{l}=\left\{\begin{array}{rr}1 & \boldsymbol{x}_{i}, \boldsymbol{x}_{j} \text { belong to a class } \\ 0 & \boldsymbol{x}_{i}, \boldsymbol{x}_{j} \text { do not belong to a class }\end{array}\right.$

در رابطة بالا، $n=\sum_{c=1}^{n_{c}} n_{t c}$ n تعداد طبقها

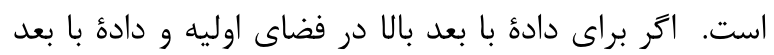
كاهشيافته در فضاى ثانويه، بهترتيب فرمهاى ماتريسى X را به شكل زير در نظر بخيريم:

$\boldsymbol{X}=\left[\boldsymbol{x}_{1}, \boldsymbol{x}_{2}, \ldots, \boldsymbol{x}_{n}\right]_{d \times n}$

(广) 


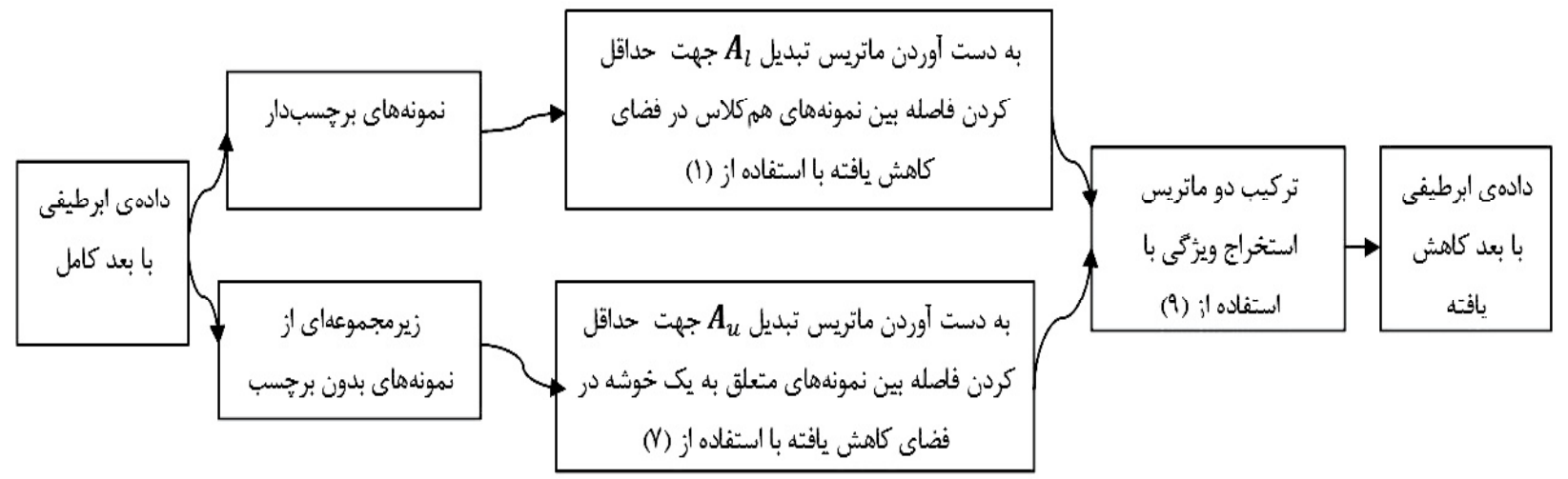

(شكل-1): نمودارجعبهاى روش پيشنهادى

(Figure-1): Block diagram of the proposed method

ابرطيفى دانشگاه ياويا از محوطة دانشگاه پاويا در ايتاليا با استفاده از سنجندهُ نورى ROSIS اخذ شده است. اين تصوير، داراى تفكيك مكانى س/ متر بر ييكسل و داراى ها |ا باند

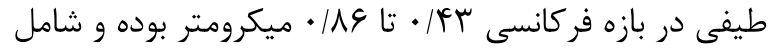

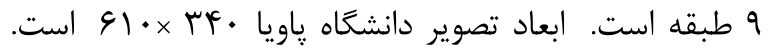
بعد از حذف كانالهاى نوفهاى، آزمايشها بر روى بـ • إناند باقيمانده انجام شده است. داده ابرطيفى ساليناس توسط لهاي سنجنده AVIRIS از دهكده ساليناس در كاليفرنياى جنوبى

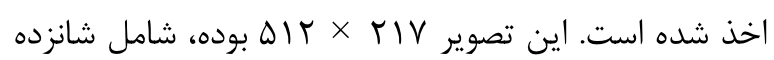

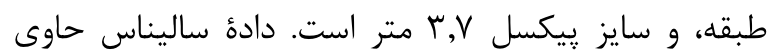

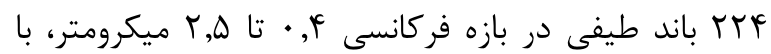
قدرت تفكيك طيفى • ا نانومتر است كه بعد از حذف بيست

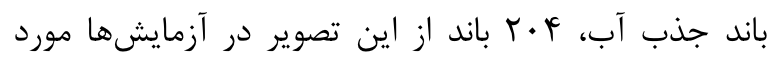
استفاده قرار مى گيرند. در اين مقاله از جندين معيار مختلف براى ارزيابى كارايى طبقهبندى استفاده مى كنيم: دقت متوسط، اعتبار متوسط و ضريب كايا [31]. دقت متوسط، ميانگين دقت بهدست آمده براى تمام طبقهها و اعتبار متوسط برابر ميانگين اعتبار بهدستآمده براى تمام طبقهها است. اعتبار براى هر كلاس

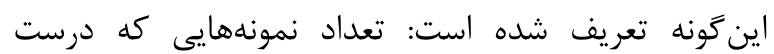

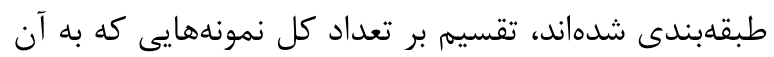
طبقه تعلق گرفتهاند. ضريب كايا '، يكى از يارامترهاى دقت است كه دقت

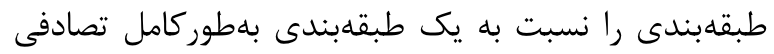

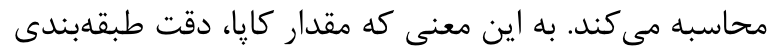
رانسبت به حالتى كه يك تصوير بهطور كامل بهصورت تصادفى مينى طبقلبندى شود، به دست مىدهد. به اين ترتيب، يك كايا

3 Salinas

4 Kappa Coefficient (KC)
آنها در نظر ترفته مى شود. مشابه روند قبلى انجام شده براى

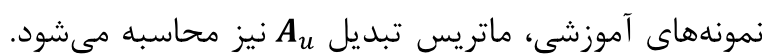
درنهايت ماتريس تبديل نهايى كه براى استخراج ويزگى داده

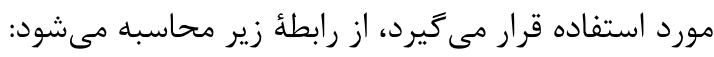

$$
\boldsymbol{A}=\alpha \boldsymbol{A}_{l}+(1-\alpha) \boldsymbol{A}_{u}
$$

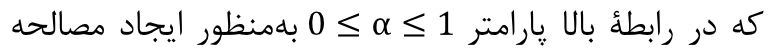

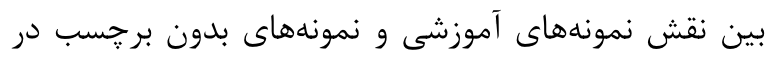

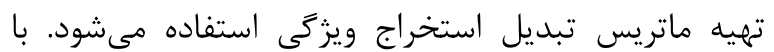

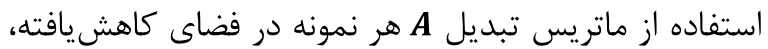
يك بردار m بعدى به شكل

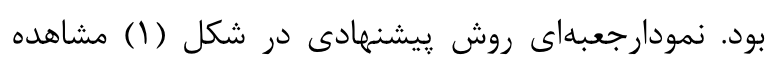
مىشود.

\section{r-ارزيابى و آزمايشها}

ما براى انجام آزمايشهاى خود در اين قسمت از سه داده

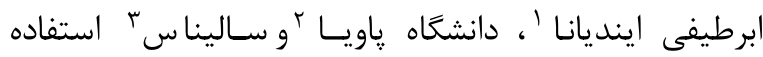

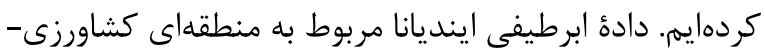
جنكلى است كه توسط سنجنده AVIRIS از شمال شرقى

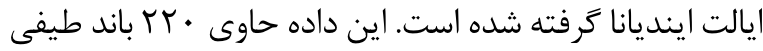

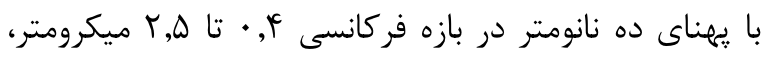

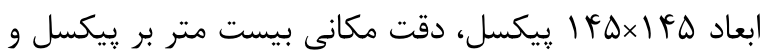
دقت راديومتريك هشت بيت است. بيست كانال نوفهاى اين داده حذف شده و آزمايشها بر روى دويست باند باقيمانده انجام مى گيرد. اين داده حاوى شانزده طبقه است. داده

2 University of Pavia 
كاهشيافته را توسط طبقهبند بردار رشتيبان ' (SVM)

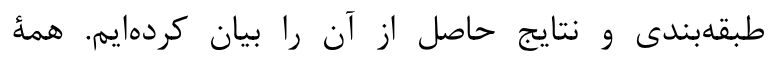

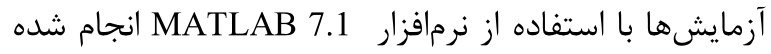

$\alpha=0$ = $\alpha=1$

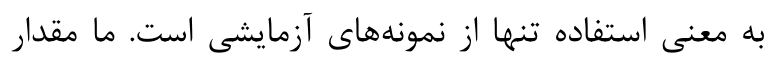

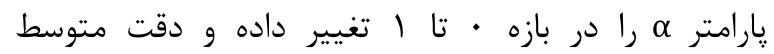

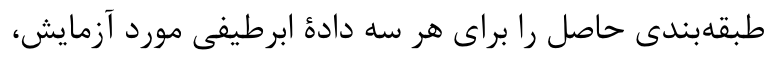

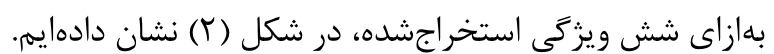
مقدار مناسب پارامتر ه براى سه دادهى اينديانا، ياويا و و

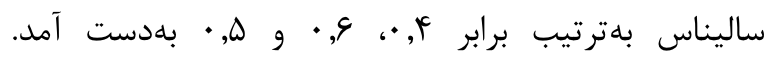

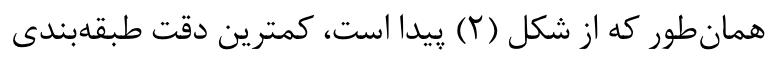

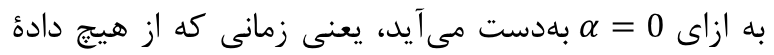

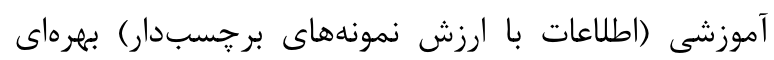
نمى

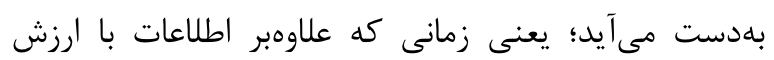

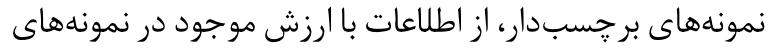
بدون برجسب خوشهبندى شده نيز استفاده مى كنيم. بهعنوان

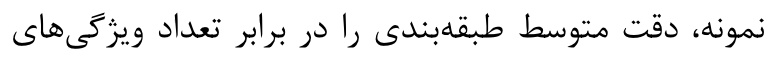
استخرجشده (m) با استفاده از روشهاى مختلف استخراج

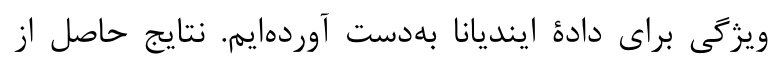

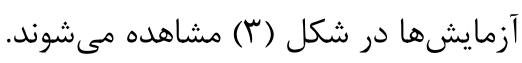

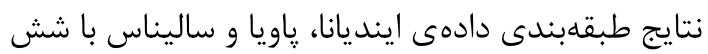
ويزگى استخراجى بهترتيب در جدولهاى (1) تا (r) مشاهده

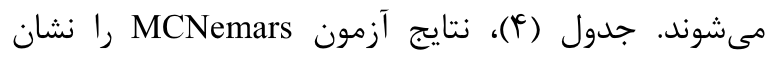

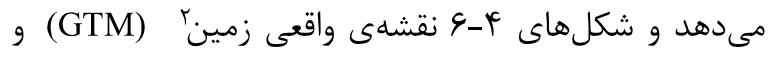

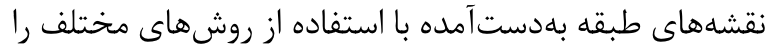

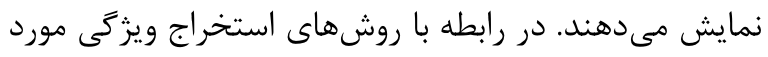
مقايسه، توجه به نكات زير ارزشمند است: • همانطوركه در جدولهاى (1) تا (r) مشاهده مىشون،

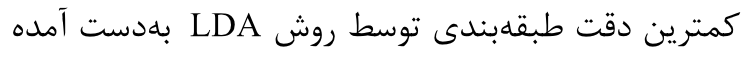

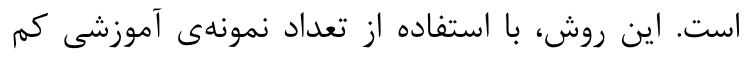

$$
\text { داراى كارايى بسيار ضعيفى است. }
$$

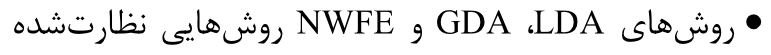

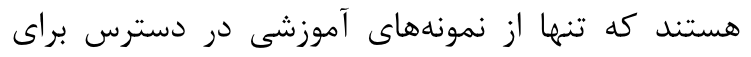

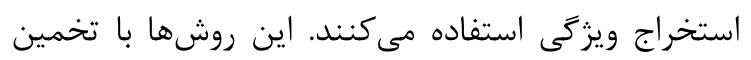
ماتريسهاى :راكندگى، سعى در كمينه كردن فاصلههاى

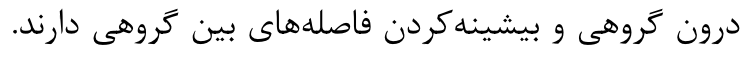

\footnotetext{
${ }^{2}$ Ground Truth Map
}

VQ معادل VD Vد به اين معنى است كه نتايج طبقدبندى

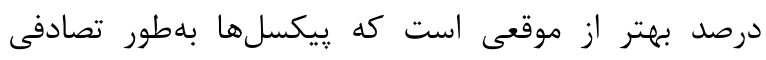

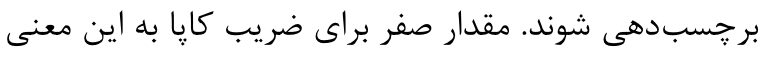

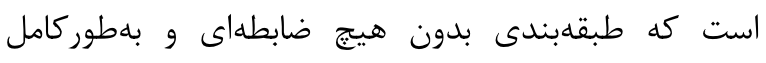

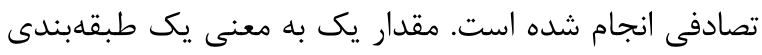

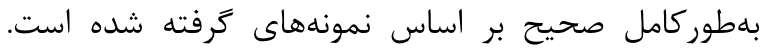

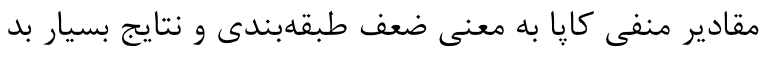

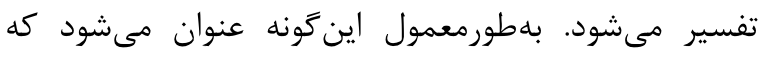

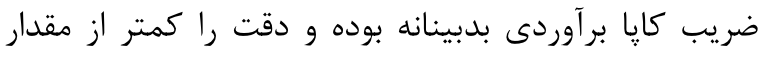
واقعى بيان مى كند. ضريب كايا بهشكل زير محاسبه مى بـ بودي:

$K C=\frac{N \sum_{c=1}^{n_{c}} t_{c c}-\sum_{c=1}^{n_{c}} t_{c+} t_{+c}}{N^{2}-\sum_{c=1}^{n_{C} t_{c+} t_{+c}}}$

در رابطؤ بالا، $N$ و ${ }^{2}$ بهترتيب تعداد نمونههاى آزمايشى و تعداد طبقهها هستند. صحيح در طبقه c طبقهبندى شدهاند، +ct

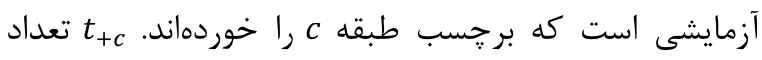

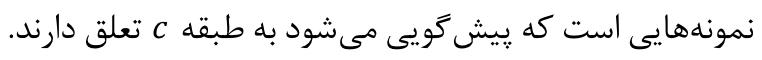

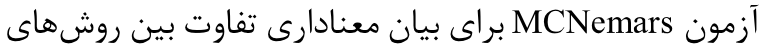

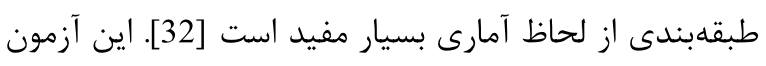
براى مقايسه بين يك جفت طبقهبند مورد استفاده قرار

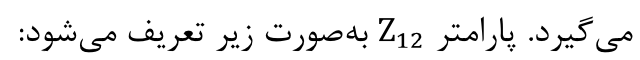
$Z_{12}=\frac{f_{12}-f_{21}}{\sqrt{f_{12}+f_{21}}}$

f تعداد نمونههايى است كه توسط طبقهبند ا درست

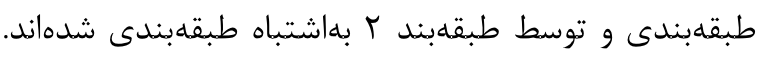
تفاوت بين طبقهبندهاى او ك از نظر آهارى، با اهميت كَفته مىشود اكر 1.96 > |

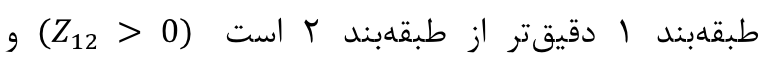

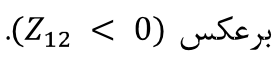
از آن جايى كه بلهطورمعمول تعداد نماد نمونههاى آموزشى در

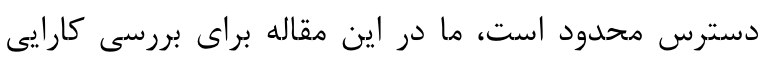

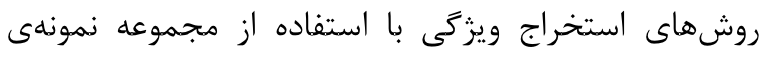

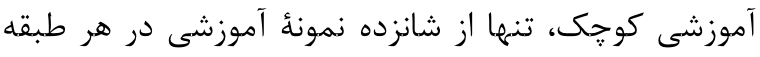

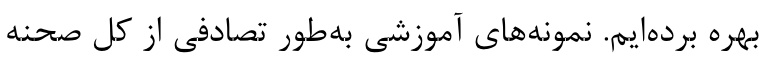

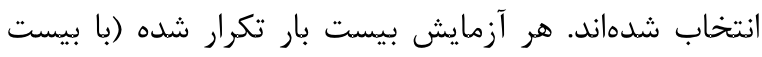

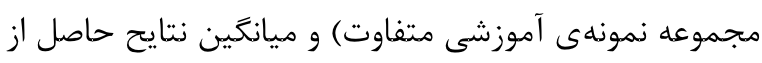
آزمايشها كزارش شده است.

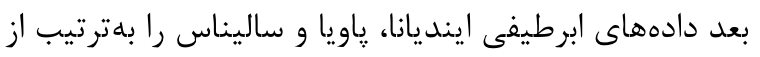

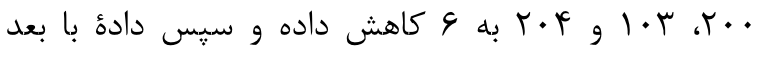

${ }^{1}$ Support Vector Machine 
روش ييشنهادى و ساير روشها هموراه مقدارى مثبت و

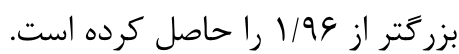

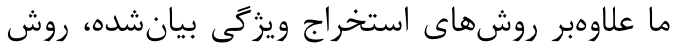
بيشنهادى خود را با دو روش استخراج ويزگى كه روسى درهميناواخر ييشنهاد شدهاند، نيز مقايسه كردهايم. روش استخراج ويزگى مورد مقايسه نخست روش SELD است كه علاوهبر نمونههاى برجسبدار از قدرت نمونههاى بدون برجسب نيز بهره مىبرد و روش دوم مورد مقايسه، روش

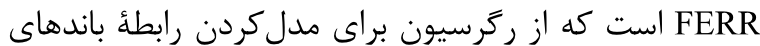
طيفى نسبت به يكديگر عمل مى كند. دقت متوسط طبقهبندى در برابر تعداد ويزگى هاى استخراجشده براى داده ياويا در شكل (V) نشان داده شده است.

(شكل - (ץ): دقت طبقهبندى در برابر هارامتر

(Figure-3): Classification accuracy versus parameter $m$

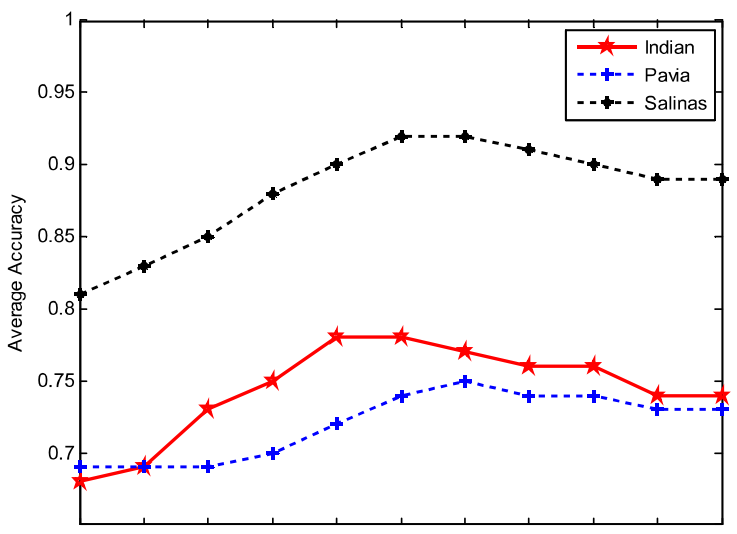

به اين ترتيب، اين روشها، بر اساس معيار جدايىيذيرى

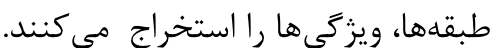
• روش PCA يك روش بدون نظارت است كه از اطلاعات نمونههاى آموزشى بهرهاى نمىبرد. روش PCA با استخراج

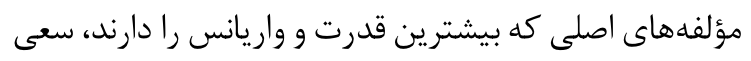
در حفظ ساختار داده در فضاى بعد كاهشيافته مى كند.

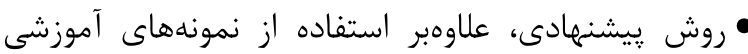
برجسبدار، از قدرت نمونههاى آموزشى بدون برجسب نيز بهره مىبرد. روش زيشنهادى، با درنظرگرفتن برجسب طبقهها در توليد گراف داده و محاسبة ماتريس شباهت، علاوه بر افزايش جدايىيذيرى سعى در حفظ ساختار داده

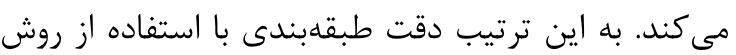
ييشنهادى افزايش مىيابد. نهتنها در جدولهاى (1) تا (ب)، بالاترين دقت طبقهبندى توسط روش קيشنهادى به دست

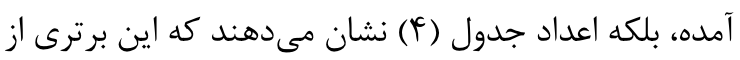
نظر آمارى نيز معنادار و قابل توجه است. يارامتر Z بين

( شكل-T): دقت طبقدبندى در برابر : يارامتر

(Figure-2): Classification accuracy versus parameter $\alpha$

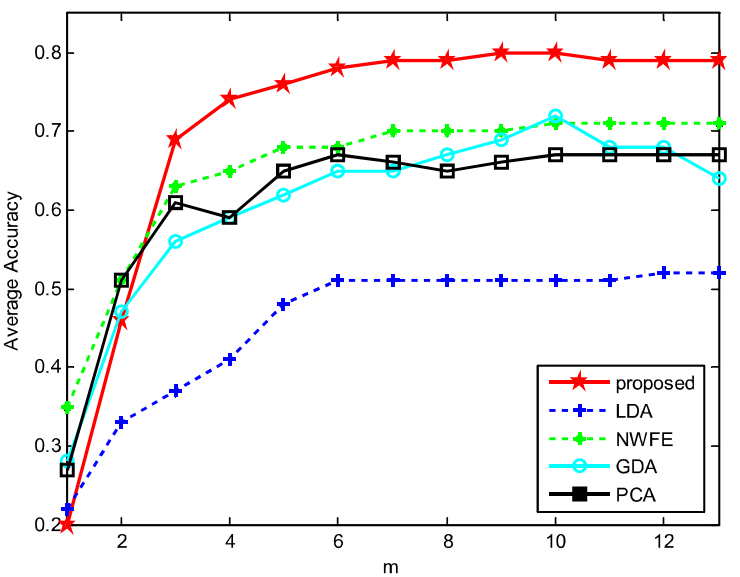

(جدول - (1): نتايج طبقهبندى دادهى اينديانا

(Table-1): Classification results for Indian dataset

\begin{tabular}{|c|c|c|c|c|c|c|c|c|c|c|c|c|}
\hline \multicolumn{3}{|c|}{ class } & \multicolumn{2}{|c|}{ Proposed } & \multicolumn{2}{|c|}{ LDA } & \multicolumn{2}{|c|}{ NWFE } & \multicolumn{2}{|c|}{ GDA } & \multicolumn{2}{|c|}{ PCA } \\
\hline No & Name of class & $\begin{array}{c}\# \\
\text { samples }\end{array}$ & Acc. & Rel. & Acc. & Rel. & Acc. & Rel. & Acc. & Rel. & Acc. & Rel. \\
\hline 1 & يونجه & 46 & 94.0 & 26.0 & 70.0 & 11.0 & 93.0 & 14.0 & 94.0 & 20.0 & 81.0 & 19.0 \\
\hline 2 & ذرت-بدون شخم & 1428 & 61.0 & 45.0 & 32.0 & 37.0 & 60.0 & 56.0 & 57.0 & 39.0 & 45.0 & 44.0 \\
\hline 3 & ذرت-كم شخم & 830 & 76.0 & 57.0 & 24.0 & 17.0 & 40.0 & 24.0 & 38.0 & 30.0 & 43.0 & 29.0 \\
\hline 4 & ذرت & 237 & 79.0 & 42.0 & 46.0 & 14.0 & 77.0 & 40.0 & 58.0 & 35.0 & 76.0 & 43.0 \\
\hline 5 & سبزه-درختان & 483 & 85.0 & 78.0 & 46.0 & 50.0 & 58.0 & 32.0 & 62.0 & 48.0 & 72.0 & 61.0 \\
\hline 6 & سبزه-جمنزار & 730 & 91.0 & 84.0 & 50.0 & 51.0 & 82.0 & 87.0 & 65.0 & 68.0 & 64.0 & 74.0 \\
\hline 7 & سبزه- جمنزار كوتاه & 28 & 00.1 & 53.0 & 88.0 & 13.0 & 92.0 & 51.0 & 92.0 & 55.0 & 96.0 & 58.0 \\
\hline 8 & كاه و خاشاك & 478 & 79.0 & 00.1 & 44.0 & 77.0 & 79.0 & 99.0 & 79.0 & 99.0 & 74.0 & 96.0 \\
\hline
\end{tabular}




\begin{tabular}{|c|c|c|c|c|c|c|c|c|c|c|c|c|}
\hline 9 & جو دوسر & 20 & 00.1 & 63.0 & 90.0 & 06.0 & 00.1 & 44.0 & 00.1 & 16.0 & 00.1 & 30.0 \\
\hline 10 & سويا-بدون شخم & 972 & 60.0 & 61.0 & 31.0 & 22.0 & 54.0 & 63.0 & 74.0 & 45.0 & 67.0 & 54.0 \\
\hline 11 & سويا-كم شخم & 2455 & 43.0 & 80.0 & 18.0 & 52.0 & 33.0 & 63.0 & 20.0 & 64.0 & 40.0 & 70.0 \\
\hline 12 & سويا-شخم كامل & 593 & 55.0 & 57.0 & 18.0 & 21.0 & 55.0 & 37.0 & 17.0 & 24.0 & 23.0 & 23.0 \\
\hline 13 & كَندم & 205 & 98.0 & 95.0 & 78.0 & 50.0 & 89.0 & 68.0 & 94.0 & 72.0 & 75.0 & 79.0 \\
\hline 14 & بيشه & 1265 & 86.0 & 95.0 & 58.0 & 90.0 & 56.0 & 83.0 & 88.0 & 91.0 & 88.0 & 91.0 \\
\hline 15 & ساختمان-سبزه & 386 & 54.0 & 54.0 & 42.0 & 25.0 & 27.0 & 58.0 & 21.0 & 56.0 & 31.0 & 32.0 \\
\hline 16 & سنگ-برج & 93 & 91.0 & 46.0 & 87.0 & 26.0 & 98.0 & 48.0 & 87.0 & 48.0 & 89.0 & 40.0 \\
\hline \multicolumn{3}{|c|}{ Average Acc. and Average Rel. } & 0.78 & 0.65 & 0.51 & 0.35 & 0.68 & 0.54 & 0.65 & 0.51 & 0.67 & 0.53 \\
\hline \multicolumn{3}{|c|}{ Kappa coefficient } & \multicolumn{2}{|c|}{$\frac{1}{0.62}$} & \multicolumn{2}{|c|}{0.29} & \multicolumn{2}{|c|}{0.48} & \multicolumn{2}{|c|}{0.47} & \multicolumn{2}{|c|}{0.50} \\
\hline
\end{tabular}

(جدول - (Y): نتايج طبقهبندى داده دانشگًاه ياويا

(Table-2): Classification results for University of Pavia dataset

\begin{tabular}{|c|c|c|c|c|c|c|c|c|c|c|c|c|}
\hline \multicolumn{3}{|c|}{ class } & \multicolumn{2}{|c|}{ Proposed } & \multicolumn{2}{|c|}{ LDA } & \multicolumn{2}{|c|}{ NWFE } & \multicolumn{2}{|c|}{ GDA } & \multicolumn{2}{|c|}{ PCA } \\
\hline No & Name of class & $\begin{array}{c}\# \\
\text { samples } \\
\end{array}$ & Acc. & Rel. & Acc. & Rel. & Acc. & Rel. & Acc. & Rel. & Acc. & Rel. \\
\hline 1 & آسفالت & 6631 & 0.51 & 0.89 & 0.31 & 0.55 & 0.64 & 0.77 & 0.52 & 0.84 & 0.15 & 0.54 \\
\hline 2 & جֵمنزار & 18649 & 0.62 & 0.89 & 0.53 & 0.84 & 0.54 & 0.82 & 0.70 & 0.81 & 0.75 & 0.86 \\
\hline 3 & شن و سنَ ريزه & 2099 & 0.60 & 0.46 & 0.49 & 0.31 & 0.56 & 0.49 & 0.47 & 0.42 & 0.71 & 0.50 \\
\hline 4 & درختان & 3064 & 0.63 & 0.81 & 0.60 & 0.67 & 0.65 & 0.75 & 0.56 & 0.74 & 0.68 & 0.72 \\
\hline 5 & صفحات فلزى & 1345 & 1.00 & 0.98 & 0.89 & 1.00 & 0.99 & 0.99 & 0.99 & 0.86 & 0.99 & 0.96 \\
\hline 6 & زمين دست نخورده & 5029 & 0.89 & 0.41 & 0.60 & 0.22 & 0.75 & 0.32 & 0.54 & 0.34 & 0.72 & 0.47 \\
\hline 7 & قير & 1330 & 0.86 & 0.30 & 0.28 & 0.14 & 0.87 & 0.40 & 0.86 & 0.30 & 0.86 & 0.18 \\
\hline 8 & آجر & 3682 & 0.64 & 0.64 & 0.26 & 0.42 & 0.59 & 0.73 & 0.69 & 0.68 & 0.57 & 0.79 \\
\hline 9 & سايه & 947 & 0.99 & 0.98 & 0.79 & 0.60 & 0.99 & 1.00 & 1.00 & 1.00 & 1.00 & 1.00 \\
\hline \multicolumn{3}{|c|}{ Average Acc. and Average Rel. } & 0.75 & 0.71 & 0.53 & 0.53 & 0.73 & $\mathbf{0 . 7 0}$ & 0.70 & 0.67 & 0.71 & $\mathbf{0 . 6 7}$ \\
\hline \multicolumn{3}{|c|}{ Kappa coefficient } & \multicolumn{2}{|c|}{0.58} & \multicolumn{2}{|c|}{0.38} & \multicolumn{2}{|c|}{0.54} & \multicolumn{2}{|c|}{0.55} & \multicolumn{2}{|c|}{0.55} \\
\hline
\end{tabular}

(جدول - r): نتايج طبقهبندى داده ساليناس

(Table-3): Classification results for Salinas dataset

\begin{tabular}{|c|c|c|c|c|c|c|c|c|c|c|c|c|}
\hline \multicolumn{3}{|c|}{ class } & \multicolumn{2}{|c|}{ Proposed } & \multicolumn{2}{|c|}{ LDA } & \multicolumn{2}{|c|}{ NWFE } & \multicolumn{2}{|c|}{ GDA } & \multicolumn{2}{|c|}{ PCA } \\
\hline No & Name of class & $\begin{array}{c}\# \\
\text { samples }\end{array}$ & Acc. & Rel. & Acc. & Rel. & Acc. & Rel. & Acc. & Rel. & Acc. & Rel. \\
\hline 1 & بروكلى- سبزه-علف هرز & 2009 & 0.96 & 1.00 & 0.96 & 0.99 & 0.98 & 0.91 & 0.95 & 1.00 & 0.96 & 0.98 \\
\hline 2 & بروكلى -سبزه-علف هرزץ & 3726 & 0.99 & 0.98 & 0.96 & 0.98 & 0.93 & 0.98 & 0.99 & 0.96 & 0.98 & 0.97 \\
\hline 3 & زمين شخم شده & 1976 & 0.95 & 0.91 & 0.67 & 0.55 & 0.97 & 0.81 & 0.84 & 0.79 & 0.97 & 0.93 \\
\hline 4 & زمين شخم شده-زبر-كاوآهن & 1394 & 0.99 & 0.97 & 0.67 & 0.81 & 0.98 & 0.92 & 0.99 & 0.94 & 0.99 & 0.99 \\
\hline 5 & زمين شخم شده-هموار & 2678 & 0.95 & 0.96 & 0.71 & 0.72 & 0.95 & 0.97 & 0.92 & 0.89 & 0.97 & 0.98 \\
\hline 6 & كاه بن & 3959 & 1.00 & 1.00 & 0.93 & 1.00 & 0.99 & 1.00 & 0.99 & 0.98 & 0.98 & 0.99 \\
\hline 7 & كرفس & 3579 & 0.99 & 0.93 & 0.97 & 1.00 & 0.98 & 0.94 & 0.96 & 0.93 & 0.98 & 0.93 \\
\hline 8 & انكَور & 11271 & 0.74 & 0.74 & 0.53 & 0.70 & 0.51 & 0.73 & 0.77 & 0.70 & 0.57 & 0.67 \\
\hline 9 & خاك-تاكستان & 6203 & 0.96 & 0.99 & 0.69 & 0.87 & 0.98 & 0.98 & 0.92 & 0.99 & 0.92 & 0.99 \\
\hline 10 & ذرت- سبزه يير -علف هرز & 3278 & 0.89 & 0.87 & 0.84 & 0.43 & 0.72 & 0.93 & 0.84 & 0.83 & 0.77 & 0.81 \\
\hline 11 & كاهو-fl هفته & 1068 & 0.98 & 0.75 & 0.85 & 0.94 & 0.75 & 0.87 & 0.93 & 0.73 & 0.98 & 0.71 \\
\hline 12 & كاهو-ه هفته & 1927 & 0.98 & 0.95 & 0.50 & 0.39 & 0.97 & 0.95 & 0.90 & 0.95 & 1.00 & 0.89 \\
\hline 13 & كاهو-4 هفته & 916 & 0.96 & 0.97 & 0.76 & 0.59 & 0.97 & 0.80 & 0.93 & 0.96 & 0.97 & 0.78 \\
\hline 14 & كاهو-V هفته & 1070 & 0.94 & 0.94 & 0.73 & 0.73 & 0.94 & 0.89 & 0.94 & 0.93 & 0.94 & 0.80 \\
\hline 15 & تاكستان & 7268 & 0.59 & 0.63 & 0.55 & 0.50 & 0.70 & 0.47 & 0.50 & 0.61 & 0.58 & 0.48 \\
\hline 16 & تاكستان-شاغولى -داربست & 1807 & 0.86 & 0.97 & 0.90 & 0.99 & 0.82 & 0.92 & 0.83 & 0.93 & 0.71 & 0.98 \\
\hline \multirow{2}{*}{\multicolumn{3}{|c|}{ Average Acc. and Average Rel. }} & 0.92 & 0.91 & 0.76 & 0.76 & 0.88 & 0.88 & 0.89 & 0.88 & 0.89 & 0.87 \\
\hline & Kappa coefficient & & \multicolumn{2}{|c|}{0.85} & \multicolumn{2}{|c|}{0.69} & \multicolumn{2}{|c|}{0.79} & \multicolumn{2}{|c|}{0.82} & \multicolumn{2}{|c|}{0.79} \\
\hline
\end{tabular}


(جدول-f)

(Table-4): MCNemars test results

\begin{tabular}{|c|c|c|c|c|c|}
\hline \multicolumn{7}{|c|}{ نتايج دادَى دانشَاه } \\
\hline & Proposed & LDA & NWFE & GDA & PCA \\
\hline Proposed & 0 & 54.59 & 11.88 & 4.66 & 6.70 \\
\hline LDA & -54.59 & 0 & -41.46 & -48.38 & -49.56 \\
\hline NWFE & -11.88 & 41.46 & 0 & -7.90 & -5.54 \\
\hline GDA & -4.66 & 48.38 & 7.90 & 0 & 1.86 \\
\hline PCA & -6.70 & 49.56 & 5.54 & -1.86 & 0 \\
\hline
\end{tabular}

\begin{tabular}{|c|c|c|c|c|c|}
\hline \multicolumn{6}{|c|}{ نتايج دادة اينديانا } \\
\hline & Proposed & LDA & NWFE & GDA & PCA \\
\hline Proposed & 0 & 85.46 & 40.23 & 62.26 & 35.19 \\
\hline LDA & 85.46- & 0 & 02.28- & 62.26- & 24.31- \\
\hline NWFE & 40.23- & 02.28 & 0 & 86.2 & 85.3- \\
\hline GDA & 62.26- & 62.26 & 86.2- & 0 & $31.7-$ \\
\hline PCA & 35.19- & 24.31 & 85.3 & 31.7 & $\mathbf{0}$ \\
\hline
\end{tabular}

\begin{tabular}{|c|c|c|c|c|c|c|}
\hline \multicolumn{7}{|c|}{ نتايج داده ساليناس } \\
\hline Proposed & LDA & \multicolumn{3}{|c|}{ NWFE } & GDA & PCA \\
\hline Proposed & 0 & 64.24 & 29.53 & 17.83 & 28 & \\
\hline LDA & -64.24 & 0 & -40.95 & -54.92 & -41 & \\
\hline NWFE & -29.53 & 40.95 & 0 & -12.52 & 1. & \\
\hline GDA & -17.83 & 54.92 & 12.52 & 0 & & 64 \\
\hline PCA & -28.66 & 41.39 & -1.78 & -14.64 & 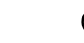 & \\
\hline
\end{tabular}

GTM

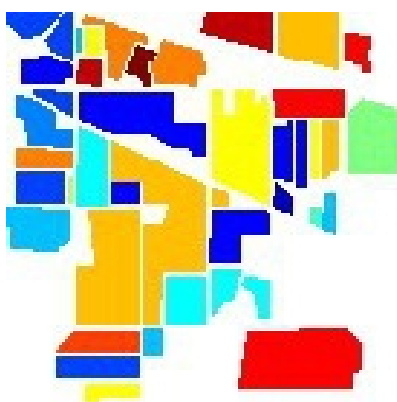

NWFE

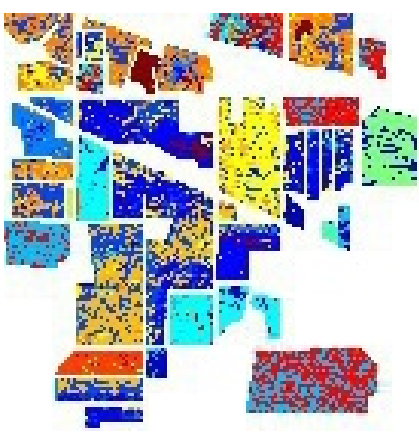

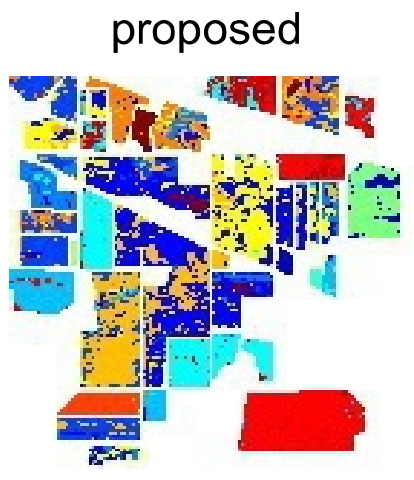

GDA

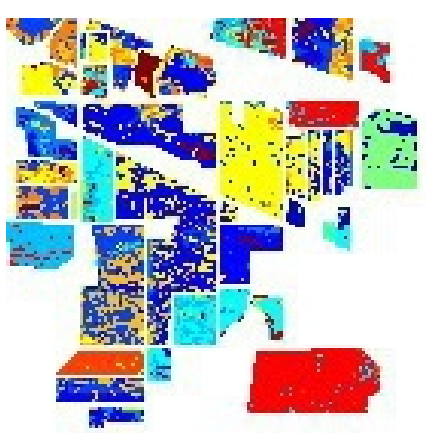

LDA

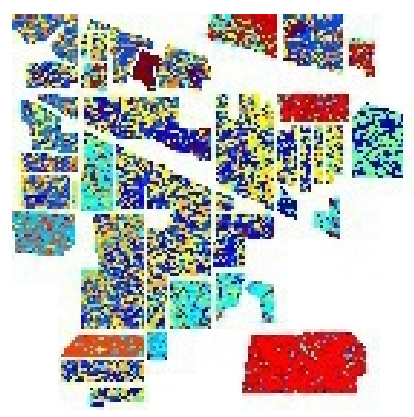

PCA

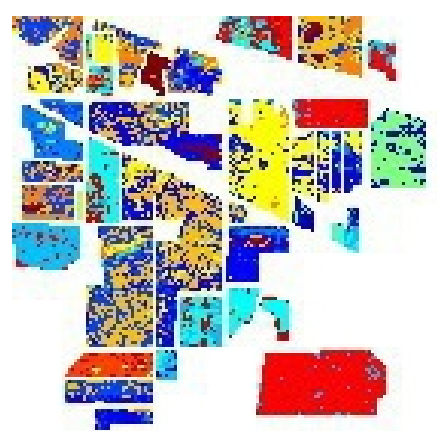

(شكل - F): : نقشه هاى طــبقةُ طبقدبندى براى داده اينديان

(Figure-4): Classification maps for Indian dataset।

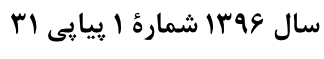



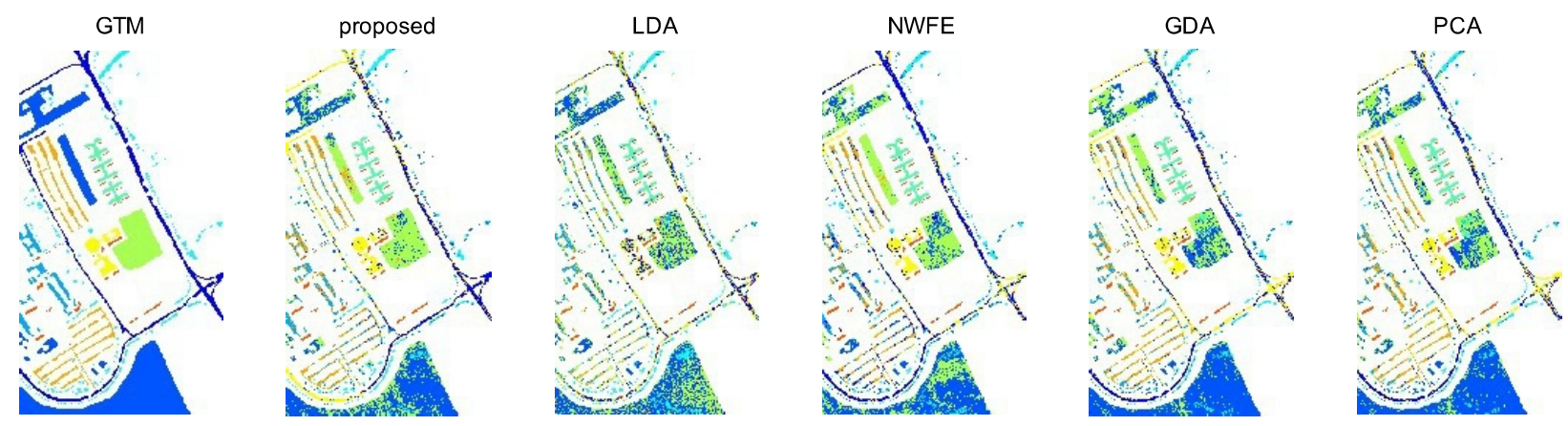

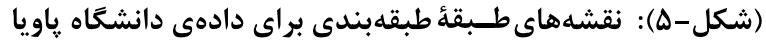

(Figure-5): Classification maps for University of Pavia dataset.
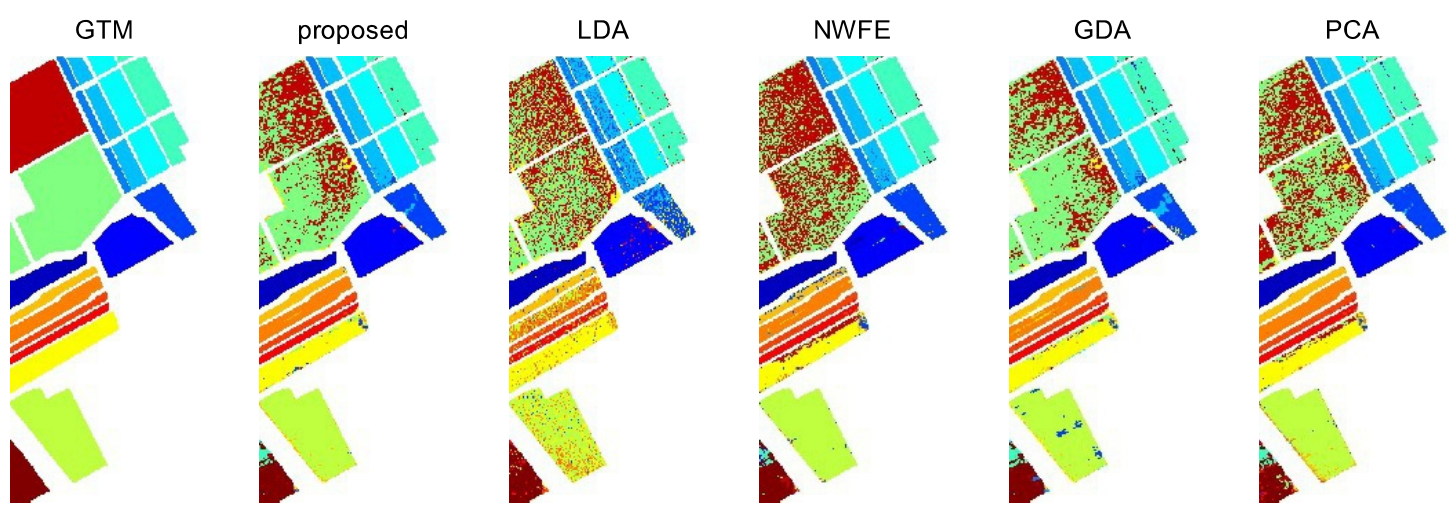

(شكل -9): نقشههاى طـبقهُ طبقدبندى براى داده ساليناس

(Figure-6): Classification maps for Salinas dataset.

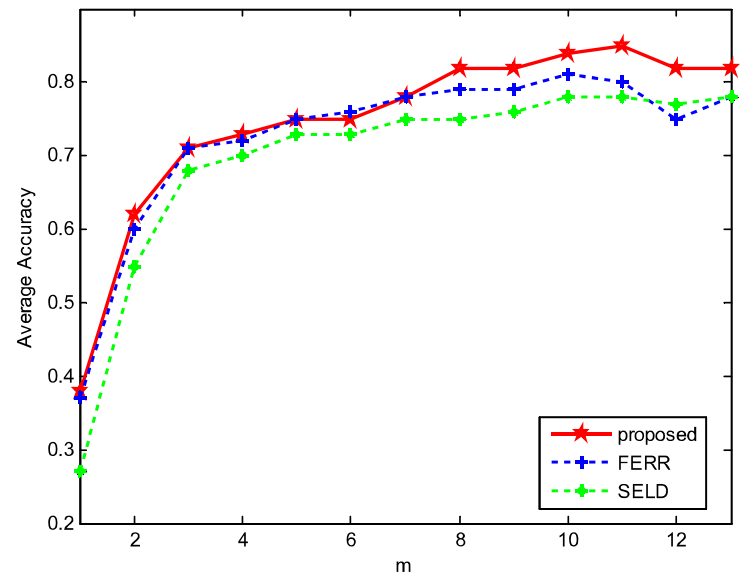

(شكل - V): مقايسه روش يِيشنهادى با روشهاى FERR و SELD در تعداد ويخَى هاى استخراج شده مختلف

(Figure-7): Comparison of the proposed method with FERR and SELD in different number of extracted features

برجسب خوشهبندىشده، باعث افزايش دقت طبقهبندى

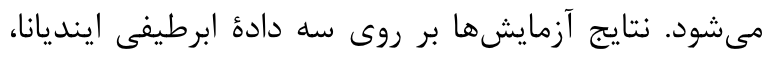

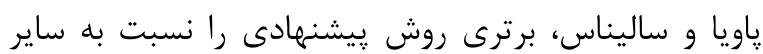

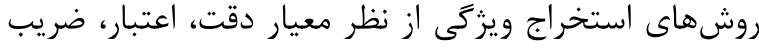

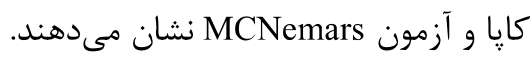

\section{P}

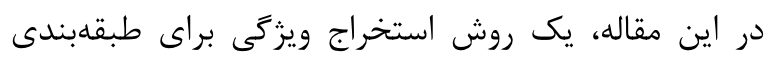

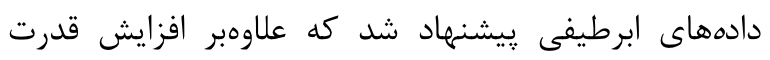
تفكيك بين طبقهها، ساختار داده را در فضاى با بعد كوجكتر

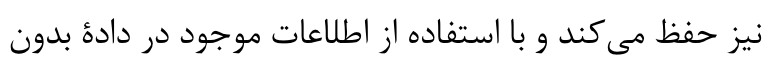


[11]H. Peng, F. Long, C. and Ding, "Feature Selection Based on Mutual Information: Criteria of Max Dependency, Max-Relevance, and MinRedundancy", IEEE Transactions on Pattern Analysis and Machine Intelligence, vol. 27, no. 8, pp. 1226-1238, 2005.

[12] J.M. Sotoca, and F. Pla, "Band selection using mutual information matrix for hyperspectral data”, marmota.dlsi.uji.es/WebBIB/papers, 2006.

[13] J. Yin, C. Gao, and X. Jia, "Using Hurst and Lyapunov Exponent For Hyperspectral Image Feature Extraction", IEEE Geoscience and Remote Sensing Letters, vol. 9, no. 4, pp. 705 709, 2012.

[14] L. Bruzzone, and C. Persello, “A novel approach to the selection of spatially invariant features for the classification of hyperspectral images with improved generalization capability", IEEE Transactions on Geoscience and Remote Sensing, vol. 47, no. 9, pp. 3180-3191, 2009.

[15] K. Fukunaga, Introduction to Statistical Pattern Recognition, Academic Press Inc, San Diego, 1990

[16] L. Zhang, L. Zhang, D. Tao, and X. Huang, "Tensor Discriminative Locality Alignment for Hyperspectral Image Spectral-Spatial Feature Extraction", IEEE Transactions on Geoscience and Remote Sensing, vol. 51, no. 1, pp. 242-256, 2013.

[17] J. Yin, Y. Wang, and J. Hu, "A new dimensionality reduction algorithm for hyperspectral image data using evolutionary strategy", IEEE Transactions on Industrial Informatics, vol. 8, no. 4, pp. 935-943, 2012.

[18]D. Lunga and O. Ersoy, "Spherical Nearest Neighbor Classification: Application to hyperspectral Data", ECE Technical Reports, Purdue University, 2010.

[19]D. Lunga and O. Ersoy, "Spherical Stochastic Neighbor Embedding of Hyperspectral Data", IEEE Transactions on Geoscience and Remote Sensing, vol. 51, no. 2, pp. 857-871, 2013.

[20] M. Zortea, V. Haertel, and R. Clarke, "Feature Extraction in Remote Sensing High-Dimensional Image Data", IEEE Geoscience and Remote Sensing Letters, vol. 4, no. 1, pp. $107-111,2007$.

[21] M. Imani and H. Ghassemian, "Assessment of Performance Improvement in Hyperspectral Image Classification Based on Adaptive Expansion of Training Samples", Journal of Information Systems and Telecommunication, vol. 2, no. 2, pp. 63-70, 2014.

\section{5-Refrences}

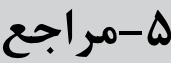

[1] G. F. Hughes, "On the mean accuracy of statistical pattern recognition," IEEE Transactions on Information Theory, vol. IT-14, no. 1, pp. 55-63, 1968.

[2] Q. Zhang, Y. Tian, Y. Yang, and C. Pan, "Automatic Spatial-Spectral Feature Selection for Hyperspectral Image via Discriminative Sparse Multimodal Learning", IEEE Transactions on Geoscience and Remote Sensing, vol. 53, no. 1, pp. 261-279, 2015

[3] J. Xia, J. Chanussot, P. Du, X. He, "SpectralSpatial Classification for Hyperspectral Data Using Rotation Forests with Local Feature Extraction and Markov Random Fields", IEEE Transactions on Geoscience and Remote Sensing, vol. 53, no. 5, pp. 2532-2546, 2015.

[4] M. Imani and H. Ghassemian, "Feature Extraction Using Weighted Training Samples", IEEE Geoscience and Remote Sensing Letters, vol. 12, no. 7, pp. 1387-1391, 2015.

[5] X. Kang, S. Li, L. Fang, J. A. Benediktsson, "Intrinsic Image Decomposition for Feature Extraction of Hyperspectral Images", IEEE Transactions on Geoscience and Remote Sensing, vol. 53, no. 4, pp. 2241-2253, 2015.

[6] L. Ladha, and T. Deepa, "Feature Selection Methods and Algorithms", International Journal on Computer Science and Engineering, vol. 3, no. 5, pp. 1787-1797, 2011.

[7] C. Persello, and L. Bruzzone, "Advanced Techniques for the Classification of Very High Resolution and Hyperspectral Remote Sensing Images", PhD Dissertation, university of Trento, 2010 .

[8] D. Korycinski, M. Crawford, J.W. Barnes, J. Ghosh, "Adaptive feature selection for hyperspectral data analysis using a binary hierarchical classifier and tabu search", IEEE Symposium on Geoscience and Remote Sensing, vol. 1, pp. 297- 299, 2003.

[9] S.B. Serpico and L. Bruzzone, "A New Search Algorithm for Feature Selection in Hyperspectral Remote Sensing Images", IEEE Transactions on Geoscience and Remote Sensing, vol. 39, no. 7, pp. 1360-1367, 2001.

[10] S. Li, H. Wu, D. Wan, J. Zhu, "An effective feature selection method for hyperspectral image classification based on genetic algorithm and support vector machine", Knowledge-Based Systems, vol. 24, pp. 40-48, 2011. 


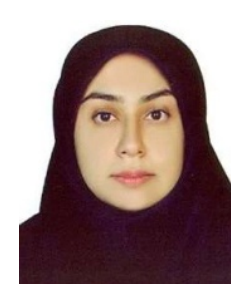

مريم ايمانى كارشناسى و كارشـــناسى

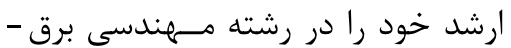

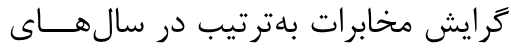

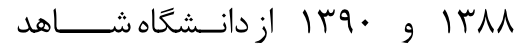

دريافت كرد. ايــشان در سال | |جساو

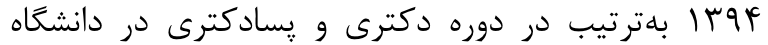
تربيت مدرس بهادامه تحصيل مشغول شد. زمينهاى يزوهشى مورد علاقهُ ايشان، شناسايى آمارى الكو، يردازش سيخَنال و اطلاعات و مهندسى سنجش از دور است. نشانى رايانامئ ايشان عبارت است از :

\section{maryam.imani@modares.ac.ir}

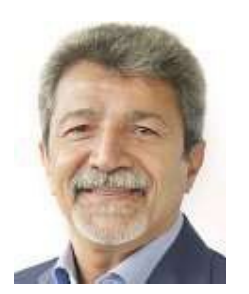

$$
\begin{aligned}
& \text { محمــد حســـن قــاســميان يزدى } \\
& \text { تحصـيلات كارشناسى خود را در رشته }
\end{aligned}
$$

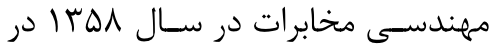

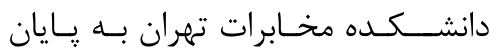

$$
\begin{aligned}
& \text { رساند. ايشان مدرك كارشناسى ارشد و }
\end{aligned}
$$

دكتراى خود را در رشـتهٔ مهندسى مخابرات در دانشعاه يردو

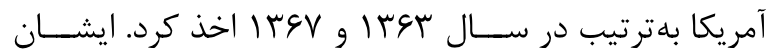
هماكنون اسـتاد دانشـكده مهندسـى برق و كامييوتر هستند.

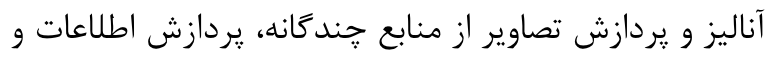
شـناسـايى الكو، مهندسـى سنجش از دور، يردازش تصاوير و سـيخنال هاى مهندسـى يزشـكى از جمله علاقههاى يزوهشى ايشان است. نشانى رايانامة ايشان عبارت است از : ghassemi@modares.ac.ir
[22] M. Imani and H. Ghassemian, "Band ClusteringBased Feature Extraction for Classification of Hyperspectral Images Using Limited Training Samples", IEEE Geoscience and Remote Sensing Letters, vol. 11, no. 8, pp. 1325 - 1329, 2014.

[23] Y.-L. Chang, J.-N. Liu, C.-C. Han, and Y.-N. Chen, "Hyperspectral Image Classification Using Nearest Feature Line Embedding Approach", IEEE Transactions on Geoscience and Remote Sensing, vol. 52, no. 1, pp. 278-287, 2014.

[24] M. Kamandar and H. Ghassemian, "Linear Feature Extraction for Hyperspectral Images Based on Information Theoretic Learning”, IEEE Geoscience and Remote Sensing Letters, vol. 10, no. 4, pp. $702-706,2013$.

[25] M. J. Mendenhall and E. Merényi, "RelevanceBased Feature Extraction for Hyperspectral Images", IEEE Transactions on Neural Network, vol. 19, no. 4, pp. 658-672, 2008.

[26]F. Tsai and J.-S. Lai, "Feature Extraction of Hyperspectral Image Cubes Using ThreeDimensional Gray-Level Cooccurrence", IEEE Transactions on Geoscience and Remote Sensing, vol. 51, no. 6, pp. 3504-3513, 2013.

[27] G. Baudat, and F. Anouar, "Generalized discriminant analysis using a kernel approach", Neural Comput., vol. 12, pp. 2385-2404, 2000

[28] B. C. Kuo, and D. A. Landgrebe, "Nonparametric weighted feature extraction for classification", IEEE Transactions on Geoscience and Remote Sensing, vol. 42, no. 5, pp. 1096-1105, 2004.

[29] W. Liao, A. Pižurica, P. Scheunders, W. Philips, Y. Pi, "Semisupervised Local Discriminant Analysis for Feature Extraction in Hyperspectral Images," IEEE Transactions on Geoscience and Remote Sensing, vol. 51, no. 1, pp. 184-198, 2013.

[30] M. Imani and H. Ghassemian, "Ridge regressionbased feature extraction for hyperspectral data", International Journal of Remote Sensing, vol. 36, no. 6, pp. 1728-1742, 2015.

[31]J. Cohen, "A coefficient of agreement from nominal scales", Educational and Psychological Measurement, vol. 20, no. 1, pp. 37-46, 1960.

[32] G. M. Foody, "Thematic map comparison: Evaluating the statistical significance of differences in classification accuracy", Photogrammetric Engineering and Remote Sensing, vol. 70, no. 5, pp. 627-633, 2004. 